\title{
Graduates' Unemployment and Entrepreneurship Quality in Tunisia
}

\section{Ibtissem OMRI}

Assistant Professor in Economics, University of Sfax, Tunisia

ibtissemomri@yahoo.fr

\begin{abstract}
This work seeks to verify the extent to which the socio-economic, cultural and political context influences the entrepreneurial intention of young Tunisian students. Particular attention is paid to the fact that the unemployment rate of tertiary graduates is strongly influencing the dynamism of entrepreneurship, especially in the "marginalized" regions. To do this, a questionnaire survey was conducted to better identify the main obstacles to entrepreneurial development. It has been clear that unemployment and the socio-economic inequalities separating the Tunisian regions have a strong influence on the adopted entrepreneurial strategy (Pull or Push strategy). This result is of paramount importance in that it explains in large part the blocking of the process of economic development in this country. The solution proposed was to call for the "visible hand" of the State in order to really realize a kind of bold entrepreneurial policy that can solve the socio-economic problems encountered by Tunisia.
\end{abstract}

Keywords- Entrepreneurial intention, Entrepreneurship, Graduates' unemployment, Regional inequality, Tunisia.

JEL classification codes

E24, J60, L26, R10

\section{INTRODUCTION}

It is now recognized that entrepreneurship is becoming one of the most important pillars of economic growth and development. Thus, economists agree that entrepreneurial economy is necessarily a dynamic, productive and jobcreating economy, despite the diversity of definitions of entrepreneurship. Indeed, the awareness of the importance of the entrepreneur in the economic activity has evolved. It began with Quesnay by giving a neutral role to the entrepreneur and placing her in the barren classroom. And it is with Cantillon, then Say, and Schumpeter followed that the foundations of entrepreneurial theory are established, while claiming that "entrepreneurial activity affects the economy as a whole" (Dejardin 2000).

Subsequent work addresses the territorial dimension of entrepreneurship and has, to some extent, called into question inter-country analyzes, including global reports, such as the Global Entrepreneurship Monitor which focuses only on differences in levels of entrepreneurial development between different countries. This type of study is considered incomplete mainly because of the absence of regional dimensions (Nlemvo and al., 2011).

In fact, within the same country, there are enormous differences in entrepreneurship (FORA 2008 and Armington and Acs., 2002). Thus, global reports that look at the entrepreneurial trajectories of countries cannot detect the regional imbalances existing in this framework (Nlemvo and al., 2011). It is for this reason that in recent years there has been a proliferation of studies that evoked the question of entrepreneurial dynamism in regional spaces (Treasury 2001, Binet and al., 2010 and Dejardin., 2010).

In order to tackle this problem, several solutions were proposed, but the design of a public policy favoring regional entrepreneurship remains the main challenge for the State. Moreover, "the lack of public sector accountability remains prejudicial to many enterprises that have limited recourses to the rule of law or corrective measures" (ADB., 2013).

This issue is of paramount importance for Tunisia. Indeed, the social uprising which broke out in Tunisia at the end of 2010, completely unveiled the failings of the development model and largely challenged the territorial management methods implemented since the in dependence. Actually, this uprising was triggered by social inequalities, the unemployment rate among graduates, poverty and corruption. As a result, the development of entrepreneurship is today a means of economic and social development of the territory, and can offer Tunisia a chance to overcome its problems. However, it also poses a major challenge to it, namely the ability to really realize a kind of bold entrepreneurial 
policy capable of fighting the socio-economic problems that have been getting worse in recent years. In other words, an appropriate strategy for economic and social development must be based on an efficient entrepreneurial strategy. Nevertheless, it is important to note that this strategy must take into account the diversity of local contexts and climates (McKenzie and Woodruff 2013).

Therefore, this work seeks to verify to what extent the socio-economic, cultural and political context influences the entrepreneurial intention in "post-revolutionary" Tunisia. Our particular attention focuses on the fact that the unemployment of graduates strongly acts on the dynamism of entrepreneurship not only on the national, but also on the regional scale.

To address this issue, we have chosen to construct our work in three sections. $i$ ) In the first section, we briefly present the reality of entrepreneurial strategies in Tunisia, while taking into account the social events that have occurred in recent years. ii) The second section proposes to analyze the factors affecting entrepreneurial intent among Tunisian students in different regional areas. iii) The aim of the last section is to highlight the different opportunities that can be offered through the realization of an efficient entrepreneurial strategy. In this context, the emphasis is on the extent of the role to be played by the Tunisian State in this framework. Several actions need to be undertaken, but rethinking public action, quantitatively and qualitatively, both internally and externally, is the mother of the reforms.

Thus, in order to study the reality of entrepreneurship in Tunisia, we have chosen to evaluate the entrepreneurial approach both at the global (compared to other developing countries) and regional level.

\subsection{The Tunisian entrepreneurial effort on a global} scale

Today, Tunisia's economic fabric is dominated by SMEs, which contribute two-thirds of the creation of wealth and employ more than $65 \%$ of the workforce. In order to better understand the entrepreneurial dynamics in Tunisia, we try to assess the position of this country in terms of entrepreneurship compared to other developing countries (inter-country study). Several indicators help to clarify the entrepreneurial position of the countries. According to the "Doing Business" report (2016), Tunisia ranks 103 rd in business creation out of 140 countries. This rank seems to be alarming, testifying the existence of structural problems which negatively affect the entrepreneurial process.

According to the Global Entrepreneurship Index 2016, Tunisia is ranked 62nd out of 132 countries with a score of 34.4, thus moving to the second category of Efficiency Driven countries.

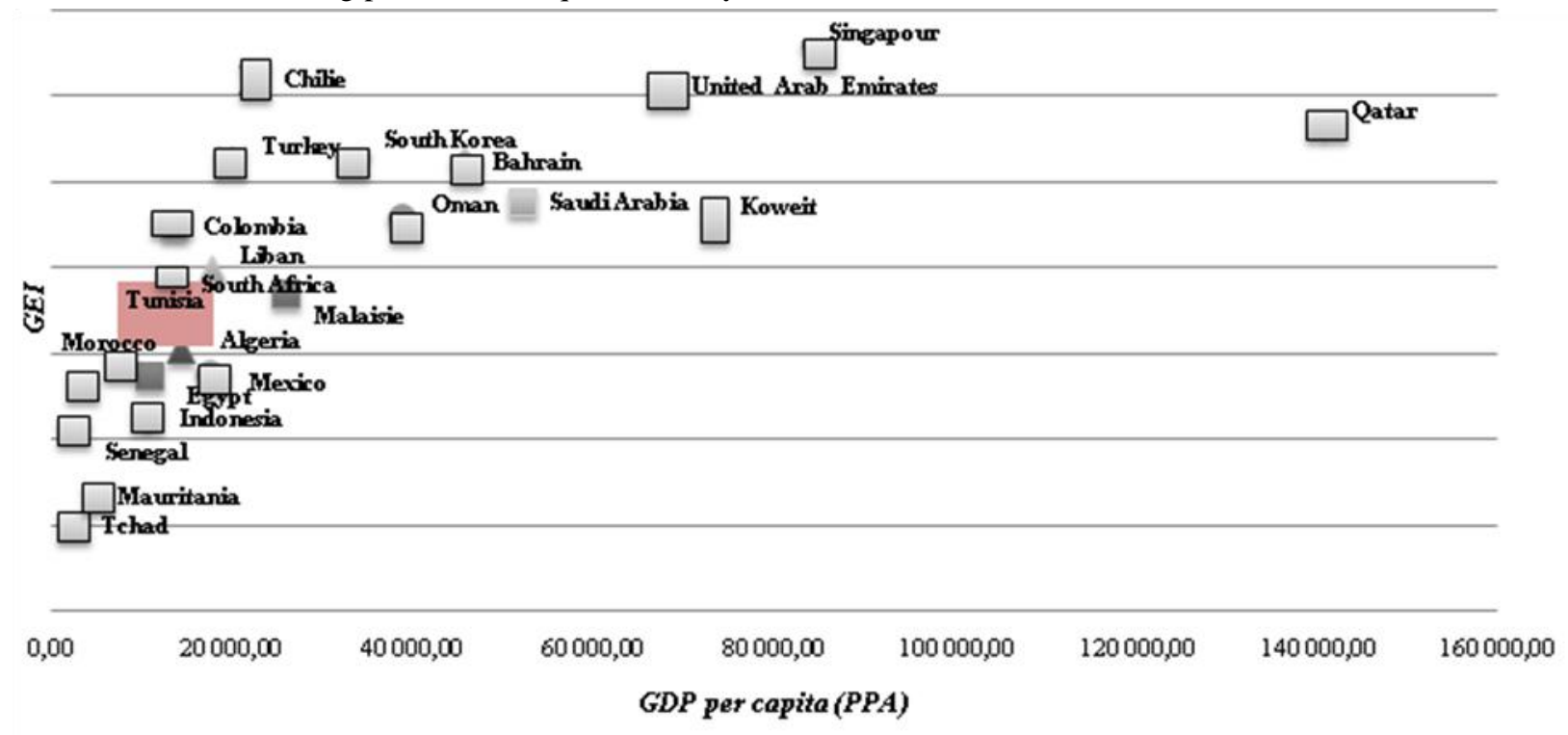

Fig.1: Evolution of GDP / has a function of the GEI

Source: Data from the World Bank and Global Entrepreneurship Index (2016)

As mentioned above, Tunisia has an average GIE position relative to other developing countries with a relatively low per capita GDP. In fact, this last report indicates that Tunisia is better ranked in terms of the perception of entrepreneurship by the company, innovative products, www.jiels.com networking. However, it is disadvantaged in terms of internationalization (0.15), human capital (0.15) and acceptance of risk (0.18).

In fact, this relatively optimistic outcome contradicts the findings of the 17th GEM (Global Entrepreneurship

Page | 1221 
Monitor) report. Tunisia is ranked 33rd out of a total of 60 countries, thus becoming the first "factor-driven" group with the lowest level of entrepreneurial development. As a result, Tunisia marked a decline in comparison with previous years in terms of the Total Entrepreneurship Activity of the first phase (TEA). This indicator measures the percentage of individuals aged between 18-64 who are novice entrepreneurs, promoters or managers of new businesses less than three and a half years old. By 2015, the TEA index was $10.1 \%$, which means that $10.1 \%$ of the population aged between 18 and 65 considered themselves active and involved in starting a new business. This index decreased between 2010 and 2012 from $6.1 \%$ to $5 \%$ in 2012 and then a 5 point increase between 2012 and 2015 .

1. 2. The entrepreneurial fiber and the dynamics of regional development

Regional disparity, which is a reality in Tunisia, was the main cause of the social movement's of 2011. It is for this reason that the entrepreneurial gap between regions is clearly observed (Figure 2), thus acting on the state of wealth creation in the regions and on the level and quality of employment.

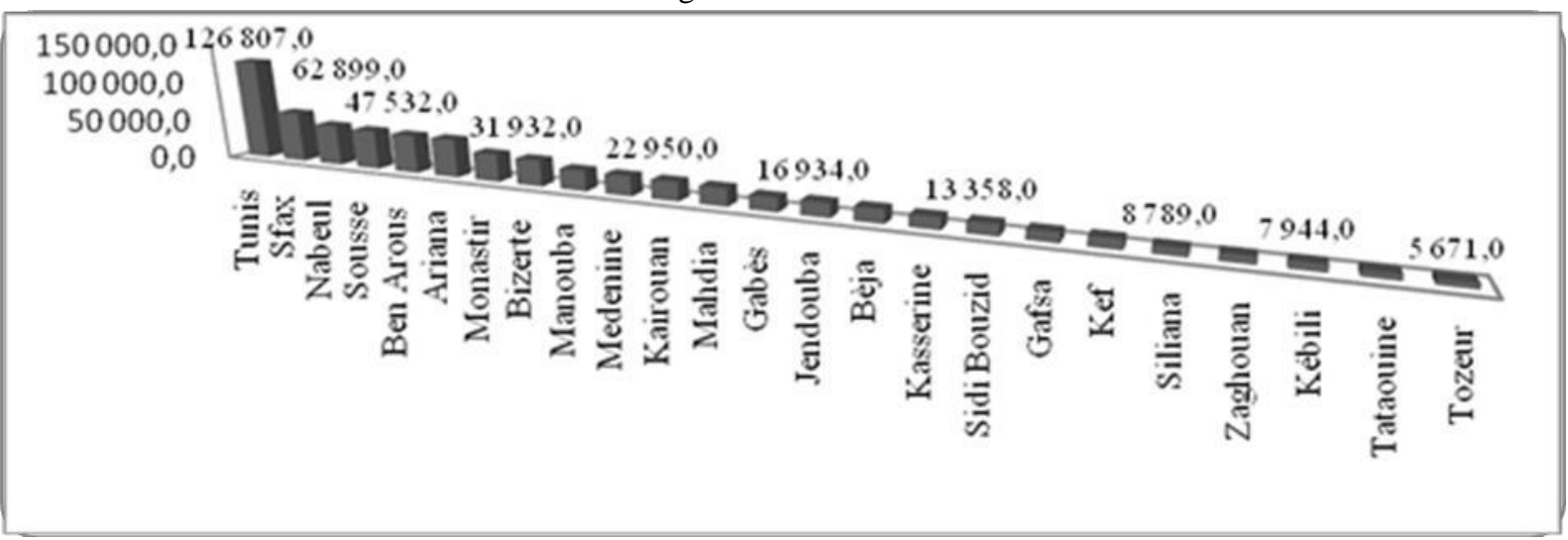

Fig. 2. Evolution of the number of companies created per Governorate (2015)

Source: INS (2015)

The regional difference in business creation is enormous. It is the northern regions and the coasts that have the highest rates of business creation compared to the internal regions. Moreover, the ratio of the pace of change in the most entrepreneurial region (Tunis) compared to the least creative region (Tozeur) exceeds 22 times. This has obvious implications for wealth creation, employment and regional development. In this order of the subject, statistics showed that $75 \%$ of the value added is concentrated in the coastal regions, accounting for $95 \%$ of the economy in industry and tourism(Baltagi 2011).
Therefore, if we take the most favored and less favored regions in terms of entrepreneurship, we can study the evolution of the disparity in this area. In fact, as shown in the table below, in 1997, the favored regions were 4.64 times more likely to create private enterprises than the less favored regions. In 2014, this report reached 6.16 times. In other words, the possibility of setting up a private enterprise in the Tunisian favored regions is more than 6 times that in the other regions.

Tab. 1. Evolution of regional entrepreneurial inequalities

\begin{tabular}{|c|c|c|c|c|}
\hline & $\begin{array}{l}\text { Private companies } \\
\text { created in } 1997 \\
\text { (average) }\end{array}$ & $\begin{array}{l}\text { Favored and less- } \\
\text { favored regions }\end{array}$ & $\begin{array}{l}\text { Private companies } \\
\text { created in } \\
2014 \text { (average) }\end{array}$ & $\begin{array}{l}\text { Favored and less- } \\
\text { favored regions }\end{array}$ \\
\hline Regions favored $^{1}$ & 28012,3 & & 56225,0 & \\
\hline $\begin{array}{l}\text { Regionsless- } \\
\text { favored regions }\end{array}$ & 6032,4 & & 9122,4 & times \\
\hline
\end{tabular}

Source: Data from the INS (2015)

\footnotetext{
${ }^{1}$ Tunis, Sfax, Nabeul, Sousse, Ben Arous, Ariana, Monastir, Bizerte.

${ }^{2}$ Gafsa, Kef, Sidi Bouzid, Siliana, Zaghouan, Kébili, Tataouine, Tozeur.
} 
It can therefore be argued that there are not only regional inequalities in terms of entrepreneurial effort but also an aggravation of these inequalities, which continue to widen over time.

In this context, a study by HM Treasury (2001), working on the entrepreneurial dynamism of the different regions of the United Kingdom, comes to mind. This study demonstrated that there are large differences in business creation, even three times between the London area and the Northeast region. Several other studies were drawn up, always in line with the same line of thinking and leading to the same conclusion. There are often regional disparities that are more or less important in terms of entrepreneurial dynamism throughout the world (Wagner and Sternberg., 2002).

This disparity was also studied by Audretsch and Keilbach (2005), who showed that the regions characterized by a high level of research and development and a low level of unemployment favor the creation of innovative enterprises. This is the case for the Tunisian regions in the north and east of the country. They benefit from the vast majority of universities, research centers and the development of industrial infrastructure. The climate is favorable not only for the creation of companies but also for their success (Wagner 1994 and Tamasy., 2006). On the other hand, the regions with high unemployment rates and low levels of innovation are more likely to stimulate the creation of low-innovative, low-technology firms, according to Audretsch and Keilbach (2005). This is the case for the internal Tunisian regions, which benefit from only a very small number of universities and are almost totally deprived of an industrial infrastructure. This is obviously a major constraint to entrepreneurial development.

As a result, it can be observed that the diversity of economic, social and cultural environments largely explains the entrepreneurial diversity, and it is the quality of the context that determines the quality of achieved entrepreneurship.

1.3 Regional entrepreneurial inequalities are accompanied by inequalities in terms of employment Regions suffer not only from entrepreneurial disparities, but also from disparities in terms of unemployment, especially among graduates. Indeed, the deterioration of the unemployment situation in Tunisia is due in part to the enlargement of the working population and to a rapid growth of the number of young people. In fact, young people aged 15 to 29 represent more than $72 \%$ of the unemployed, according to the 2012 statistics, and the unemployment rate in this category rose to $35.2 \%$ (Ministry of Vocational Training and of Employment 2012).
In Tunisia, the most educated are the most exposed to unemployment as they find it more difficult to get jobs. Moreover, for Abdih (2011), "it is among the most graduated that unemployment is the highest". Similarly, a study of Tunisia showed that the risk of long-term unemployment is higher when the population is graduated, especially for technicians and middle managers (Lakhoua 2010).

In fact, the unemployment rate of graduates rose rapidly from 3.8 per cent in 1994, from 14 per cent in 2005 to 22 per cent in 2009 to 33.5 per cent in 2013 (INS 2013), then, recorded a slight decrease in the first quarter of 2014 when it dropped to $31.4 \%$. University graduates in 1987 were almost 4000 people, reaching more than 76000 graduates in recent years (Haddar 2011), thus multiplying 19 times during this period. For this country, the most excluded from the labor market of higher graduates are the exact science teachers $(29 \%)$ followed by senior technicians $(27 \%)$. The most remarkable thing here is that almost a quarter of graduates of higher education still believe that their degree is the appropriate means of ensuring good integration into the labor market (ILO., 2014).

The most surprising in this wake is the worsening of regional inequalities in the unemployment of higher education graduates. While this rate does not exceed $11.2 \%$ in Ariana, $13.9 \%$ in Tunis and $18.1 \%$ in Sousse and Sfax it even reached $40.2 \%$ in Sidi Bouzid, $41.3 \%$ in Kébili and 46.5\% in Gafsa (Touhami., 2012).

Therefore, it seems clear to us the coexistence of entrepreneurial inequalities and inequalities in terms of the unemployment of graduates between the different Tunisian regions. In addition, the poor quality of entrepreneurship in this country, compared to other countries, appears clear in the international rankings. Thus, in the following paragraph, we empirically test this idea, in other words, we will examine the impact of the regional context, in particular, the intensity of unemployment among graduates on the entrepreneurial intention of people from different Tunisian regions.

\section{THE DETERMINANTS OF ENTREPRENEURIAL INTENT IN THE DIFFERENT TUNISIAN REGIONS}

At the level of studies and world reports, the majority of studies have focused on the difference between countries in terms of entrepreneurial strategy but only a few dealt with the regional disparity that exists within the same economy. For this reason, the follow-up of standard approaches and the application of the models developed for well-defined contexts obviously constitute a brake on local entrepreneurship and a deficiency in terms of decentralization at the territorial development level. This 
makes the recommendations of these studies incapable of providing an appropriate framework for the authorities to support the economic development of their countries, especially for a country like Tunisia. Hence, endogenous practices must be given more importance in the development of local businesses (Naudé., 2009), and entrepreneurship must be more "contextualized".

Therefore, the question that arises in this wake is how the culture of a region and the conditions it imposes act on the entrepreneurial intentions of the people who live there. Julien and Marchesnay (1996) believe that the region is only an entity that has its own policies to support entrepreneurship. Consequently, the success of a national entrepreneurial policy remains inherent in regional policies with industrial and entrepreneurial foundations certainly heterogeneous but complementary. This idea was confirmed by the work of Abdessalam et al., (2002) who studied the case of two different regions. According to them, the profile of creators and entrepreneurs differs according to the region. It is within this context that several researchers have proposed the establishment of an Entrepreneurial Development System (SDE), in order to restore the social capital of the designated regions and further consolidate their entrepreneurial efforts.

Some authors (Brusco 1986, Garofoli., 1993) argue that some regions are naturally more entrepreneurial than others, and some territories are more dynamic than others. Socio-cognitive theories of entrepreneurship, which integrate individual and contextual dimensions into the explanation of entrepreneurial behavior, (Lent, Brown, and Hackett., 2002), are also included. Thus, this section tries to test the entrepreneurial intention among Tunisian students belonging to different regions. One seeks to verify whether the socio-economic disparity and the intensity of unemployment among graduates observed between the different governorates really act on the entrepreneurial intention of the persons or not. This research is of great importance because mastering the entrepreneurial intent phase enables you to master the entire entrepreneurial process.

\section{1 Theoretical Framework}

Our theoretical base is diversified. We actually rely on the social psychology of intention (Ajzen., 1991), the intensity of the entrepreneurial event (Krueger 1993), and even on the degree of individual commitment to the entrepreneurial process linked to its environment (Learned 1992, Hernandez 2001, Hayton, George and Zahra., 2002). In any event, we will focus on two broad categories of factors; contextual and cultural factors. Let us follow the ideas of Vesalainen and Pihkala (1999), which assume that two schools have a significant effect on entrepreneurship, namely the human and the environmental schools.

Thus, in culture, and according to Davidson and Wiklund (1997), "culture is behavior". Culture has a sociological dimension that certainly acts on the entrepreneurial behavior of the individual. This can only be the result of investment in human capital, education, training and learning acquired by the individual. The impact of entrepreneurial education programs on entrepreneurial intent was already proven by Block and Stumpf (1992) and Fayolle and Gailly (2005).

As a result, we will verify whether "culture can be conceived as the regulator and catalyst of the relationship between contextual factors and entrepreneurial behavior" or not. To simplify our work, we insist on the role played by universities, in other words, we will check whether the university programs taught can be adapted to the entrepreneurial context or not. Our first hypothesis to be verified will then be:

H1: Entrepreneurial training in universities positively influences entrepreneurial intent.

At the level of the other contextual factors, we choose to deal mainly with:

i) Social elements, including family support and family status. Moreover, Retailleau (2011) thinks that "family capitalism then shows its superiority over financial capitalism". Similarly, Bossinand al., (2008) believe that the fact that one parent is an entrepreneur increases the probability of generating new entrepreneurs among the children.

H2.1: The family context positively influences the entrepreneurial intention,

H2.2: The family context positively influences entrepreneurial training,

ii) Regional factors, such as the effect of a fairly high unemployment rate and the state of the region's infrastructure, in particular the entrepreneurial infrastructure.

H3.1: The regional context positively influences entrepreneurial intent,

H3.2: The regional context positively influences entrepreneurial training,

iii) Political factors; whether the degree of democracy (or autocracy) felt by individuals and political (in) stability push them to create more businesses.

H4: The political context positively influences the entrepreneurial intention.

Our conceptual model will then be as follows: 


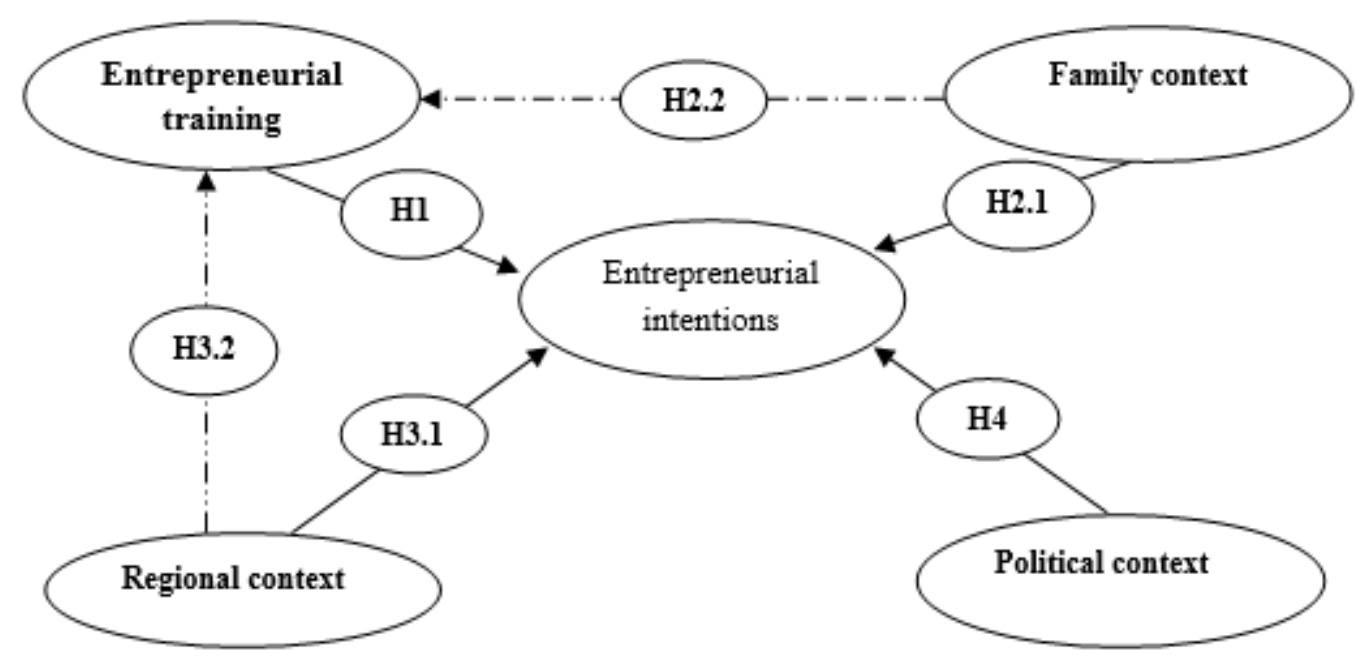

Diagram. 1. Hypothetical model of a "contextualized" entrepreneurial intention

\section{2. Methodological framework}

We choose to distribute a questionnaire over a considerable number of Tunisian students, but belong to different regions. We will test their entrepreneurial intention, in order to detect its main determinants, especially those related to the regional context of the interviewees. To do this, we launched this questionnaire for five different regions: Tunis, Sousse, Monastir, Sidi Bouzid, Sfax and Medenine. However, it is important to mention that our choice was essentially dictated by the large developmental gap separating these different regions (Fig. 3). Then, at the top of the list of governorates classified according to the Index of Regional Development (IDR), one first finds Tunis, SousseMonastir, then Sfax and Medenine and at the bottom, Sidi Bouzid, which is the least favored in terms of development in our sample. This ranking remains the same for the unemployment rate of graduates.

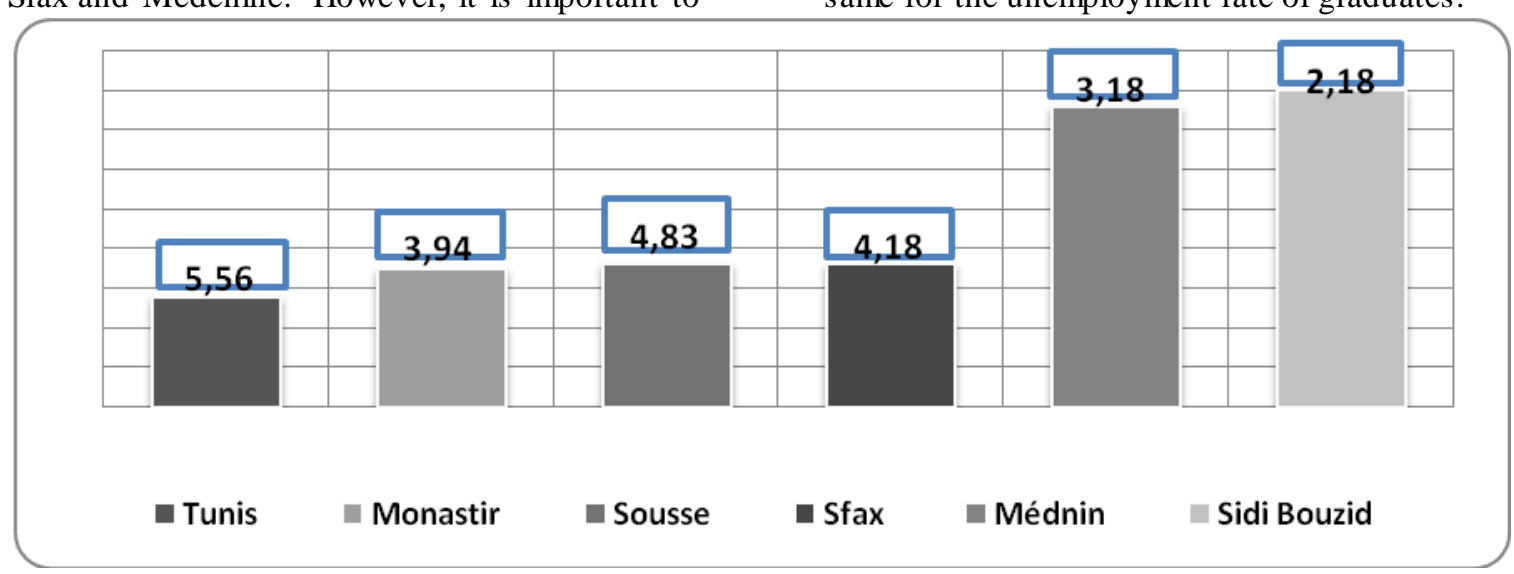

Fig. 3: Regional disparity in graduate unemployment and business climate

Source: Ministry of Regional Development and Planning

NB: Values in blue tiles represent the unemployment rate of graduates of higher education in each governorate.

If we take into account the general local index of the business climate, we can easily notice the difference between the different governorates. The governorate of Tunis is ranked 1st with a score of 5.56 , by cons Sidi Bouzid is in the 23rd place (penultimate nationally).

It can then be clearly seen that the business climate and the level of unemployment of tertiary graduates go in opposite directions. The regions with the most disadvantaged business climate have the highest unemployment rate and vice versa.
For this reason, our questionnaire is composed of several items inspired by the work of the researchers and the review of the literature. Each group of items deals with a well-defined dimension (a social and contextual, psychological, cultural and cognitive, economic and political dimension).

Likert scales with five positions, from "not at all" to "quite", were used to measure people's intent, perceptions and beliefs about the creation of businesses in different Tunisian regions.

Page | 1225 


\subsection{Sample selection and description}

The questionnaire is sent only to students from the regions mentioned above. It should be recalled that our choice was motivated not only by a geographical and spatial disparity, but also by an economic and social disparity.

Our sample is made up of 106 students, $60.4 \%$ of whom are women. The average age range is $21-25$ years. The highest percentage of students comes from Sfax (30 interviewees), while the lowest is from Grand Tunis (13 interviewees). The majority of students attend or have completed university studies in economics and management $(44.3 \%)$, and half of the interviewees reached a much higher level of studies (5th year or more). $13.8 \%$ of people currently own a business, while $16.3 \%$ are in the start-up phase.
Our sample seems representative as it covers both northern and southern regions, coastal and internal regions, to take into account all the Tunisian students and their different environments and contexts.

\subsection{Results and Conclusions}

A first pre-test was conducted with the questionnaire, which enabled us to ensure that the various statements were understood. Subsequently, an electronic version of the questionnaire was launched.

\section{Validation of measurement scales}

The analysis of the psychometric properties of the scales makes it possible to establish the validity (convergence) and the reliability of the measurement model of the present research.

Tab 2. Summary of Results of Descriptive Analyzes

\begin{tabular}{|c|c|c|c|c|c|c|c|c|c|}
\hline Variables & Items & $\begin{array}{c}\text { Index } \\
\text { of } \\
\text { KMO }^{3}\end{array}$ & $\begin{array}{l}\text { Factor } \\
\text { weight }\end{array}$ & $\begin{array}{c}\text { Quality of } \\
\text { representation }\end{array}$ & $\begin{array}{l}\text { Cumulative } \\
\text { variance }\end{array}$ & Average & Variance & $\begin{array}{l}\text { Standard } \\
\text { deviation }\end{array}$ & $\propto$ decronbac \\
\hline \multirow{6}{*}{$\begin{array}{l}\text { Entrepreneurial } \\
\text { intentions }\end{array}$} & IE1 & ,754 &, 536 & ,589 & 69,774 & 19,2642 & 36,977 & 6,08089 & ,794 \\
\hline & IE2 & & ,686 & ,658 & & & & & \\
\hline & IE3 & &, 842 & ,762 & & & & & \\
\hline & IE4 & &, 813 & ,803 & & & & & \\
\hline & IE5 & & ,732 & ,768 & & & & & \\
\hline & IE6 & & ,717 & ,707 & & & & & \\
\hline \multirow{2}{*}{$\begin{array}{l}\text { Entrepreneurial } \\
\text { training }\end{array}$} & FE1 & ,500 & ,769 & ,591 & 59,113 & 6,6750 & 3,108 & 1,76302 & ,704 \\
\hline & FE2 & & ,769 & ,591 & & & & & \\
\hline \multirow[t]{7}{*}{ Family context } & CF1 & ,842 & ,743 & ,724 & 74,151 & 20,8500 & 58,154 & 7,62591 & ,872 \\
\hline & CF2 & & ,751 & ,818 & & & & & \\
\hline & CF3 & & ,847 & ,764 & & & & & \\
\hline & CF4 & & ,720 & ,732 & & & & & \\
\hline & CF5 & & ,784 & ,615 & & & & & \\
\hline & CF6 & & ,850 & ,745 & & & & & \\
\hline & CF7 & & ,766 & ,794 & & & & & \\
\hline \multirow[t]{7}{*}{ Regional context } & CR1 & ,540 &, 531 & ,777 & 63,957 & 22,3125 & 17,964 & 4,23844 & ,726 \\
\hline & CR2 & & ,666 & ,712 & & & & & \\
\hline & CR3 & & ,689 &, 821 & & & & & \\
\hline & CR4 & & ,709 & ,771 & & & & & \\
\hline & CR5 & & ,694 & ,714 & & & & & \\
\hline & CR6 & & ,728 & ,617 & & & & & \\
\hline & CR7 & &, 561 & ,639 & & & & & \\
\hline \multirow[t]{3}{*}{ Political context } & CP1 & ,548 &, 584 & ,764 & 55,653 & 3,0189 & ,476 & 68981 & ,787 \\
\hline & CP2 & &, 570 & ,686 & & & & & \\
\hline & CP3 & & ,515 & ,761 & & & & & \\
\hline
\end{tabular}

\footnotetext{
3 The Kaiser-Meyer-Oklin (KMO) test seeks to verify the inter-correlation of variables. Its measurement must be acceptable and have a value greater than 0.5 .
} 
According to the table above, the principal component factor analysis gives a single factor for each of the variables studied, accounting for more than $50 \%$ of the total variances of the original data for all the 5 variables. Factor contributions are large and positive for all the items (> 0.6). The quality of representation is also positive and significant for all the items (>0.4). Therefore, we keep all the items in the analysis.

To evaluate the internal consistency of the scales used in this research, we performed a reliability analysis by calculating the Cronbach Alpha coefficient. The table above shows that $\alpha>0.7$ for all the variables. Therefore, the homogeneity of this scale can be considered respectable as advocated by DeVellis (2003), or acceptable as suggested by Nunnally (1978). The scale is then reliable and usable for subsequent analyses.

Verification of research hypotheses

The analysis of correlations and multiple regressions was thus performed. All analyses performed are presented in the tables below. An examination of the possible multicollinearity effect was performed by observing the Variance Inflation Factor (VIF) which attests to the absence of a multicollinearity effect $(\mathrm{Vif}<10)$.

Tab 3.Correlations between the dependent and independent variables

\begin{tabular}{|c|c|c|c|c|c|c|}
\hline & & 1 & 2 & 3 & 4 & 5 \\
\hline \multirow[t]{3}{*}{$\begin{array}{l}\text { 1. Entrepreneurial } \\
\text { intentions }\end{array}$} & $\begin{array}{l}\text { Pearson'scorrelat } \\
\text { ion }\end{array}$ & 1 & & & & \\
\hline & Sig. (bilatérale) & & & & & \\
\hline & $\mathrm{N}$ & 106 & & & & \\
\hline \multirow[t]{3}{*}{$\begin{array}{l}\text { 2. Entrepreneurial } \\
\text { training }\end{array}$} & $\begin{array}{l}\text { Pearson's correlat } \\
\text { ion }\end{array}$ &, 134 & 1 & & & \\
\hline & Sig. (bilatérale) & ,237 & & & & \\
\hline & $\mathrm{N}$ & 80 & 80 & & & \\
\hline \multirow[t]{3}{*}{ 3. Familycontext. } & $\begin{array}{l}\text { Pears on's correlat } \\
\text { ion }\end{array}$ &,- 037 &,- 065 & 1 & & \\
\hline & Sig. (bilatérale) &, 742 &, 570 & & & \\
\hline & $\mathrm{N}$ & 80 & 80 & 80 & & \\
\hline \multirow[t]{3}{*}{ 4. Regionalcontext } & $\begin{array}{l}\text { Pears on's correlat } \\
\text { ion }\end{array}$ &, $240^{*}$ &, 036 &, 051 & 1 & \\
\hline & Sig. (bilatérale) & ,032 &, 754 & ,651 & & \\
\hline & $\mathrm{N}$ & 80 & 80 & 80 & 80 & \\
\hline \multirow[t]{3}{*}{ 5. Politicalcontext } & $\begin{array}{l}\text { Pearson's correlat } \\
\text { ion }\end{array}$ &,- 020 &,- 165 &,- 122 &, 034 & 1 \\
\hline & Sig. (bilatérale) & ,839 & ,143 & ,280 & ,766 & \\
\hline & $\mathrm{N}$ & 106 & 80 & 80 & 80 & 106 \\
\hline
\end{tabular}

Table 3 presents the correlations between the analyzed variables (dependent and independent variables). We notice that the variable "Political context" is negatively correlated with "entrepreneurial intent", which shows that the intention to undert ake is higher among people who feel more democratic.

The next step refers to the regression method to verify the direct dependency assumptions. We begin with the multiple regression of the variable "entrepreneurial intention" the results of which are summarized in table 4.

Tab 4. Multiple regression for entrepreneurial intent

\begin{tabular}{|c|c|c|c|c|c|}
\hline & Beta (t) & $\mathbf{R}^{2}$ & Adjusted $R^{2}$ & $\mathbf{F}$ & Vif \\
\hline $\begin{array}{c}\text { Entrepreneurial } \\
\text { training }\end{array}$ & ,121* & 0,375 & 0,368 & $8,525 * * *$ & 1,038 \\
\hline Family context. &,- 042 & & & & 1,026 \\
\hline Regional context & ,238** & & & & 1,006 \\
\hline Political context &,- 006 & & & & 1,050 \\
\hline
\end{tabular}

Significance threshold: $* * * p<0.001, * * p<0.05, * p<0.1$ 
The results of the multiple regression analysis allow the verification of the direct dependency relations existing between the four levels of the model taken in pairs. These results show through the examination of the Beta $(\beta)$ coefficients that:

- The direct dependence hypothesis (which assumes a direct and positive influence between entrepreneurial training and entrepreneurial intent) is confirmed, which validates the overall relationship between these two variables.

- The other hypothesis of direct dependence (the regional context influences the entrepreneurial intention) is verified, validating the relationship between these two variables.

This analysis of multiple regressions confirms the hypotheses of the model; H1 and H3.1. On the other hand, hypothesis $\mathrm{H} 2.1$ and $\mathrm{H} 4$ are rejected.

To test the validity of hypotheses H2.2 and H3.2, a multiple regression was performed for the latent variable "entrepreneurial training. The results of the regression are shown in table 5.

Tab 5. Multiple regression for entrepreneurial training

\begin{tabular}{lccccc}
\hline & Beta $(\mathbf{t})$ & $\mathbf{R}^{\mathbf{2}}$ & Adjusted $^{\mathbf{2}}$ & F & Vif \\
\hline Family context & 067 & $\mathbf{0 , 1 9 6}$ & $\mathbf{0 , 1 8 0}$ & $\mathbf{5 , 2 2 0 * * *}$ & 1,003 \\
Regional context &, $039^{* *}$ & & & & 1,003 \\
\hline
\end{tabular}

Seuil de significativité : Significance threshold $* * * p<0.001, * * p<0.05$.

More than $19 \%$ of the variance of entrepreneurial training is explained. From the results, we can conclude that only the regional context positively influences entrepreneurial training with a positive and significant coefficient of 0.039. The regional context therefore has a double effect; an effect on entrepreneurial intent and an effect on entrepreneurial training. Thus, hypothesis H3.2 is validated but hypothesis $\mathrm{H} 2.2$ is rejected.

\section{Discussion of results}

The first conclusion to be drawn is the importance of entrepreneurial training and education for entrepreneurial intent. Verstraete (1999), Tounès (2003) and Gasse (2003) argue that the development of entrepreneurial potential among young people certainly requires an important investment in entrepreneurial training. This is of paramount importance for the University in the formation of entrepreneurial intent, and many studies advocate the need to transform the "traditional university" into an "entrepreneurial university" by engaging it more in innovation and performing internal and external mutations (Rajhi., 2011).

The second conclusion relates to the negative influence exerted by the family context on the entrepreneurial intention of the students. At first sight, this result seems contradictory to the ideas of Bossin et al., (2008) and Retailleau (2011), however, if we take into account the specificities of Tunisian families, particularly financial ones, we can grasp this limited effect on entrepreneurial intent. Indeed, $37 \%$ of students confirm that they can obtain funding from their families and friends, but this rate represents only $30 \%$ in Sidi Bouzid (the least favored region in our sample). These percentages are considered low, and this is certainly due to low parental incomes, with $69.2 \%$ of fathers having average incomes, while
$64.5 \%$ of mothers have low incomes. This confirms that the majority of the Tunisian population belongs to the middle class. Thus, the largest proportion of respondents with low-income fathers is registered in Sidi Bouzid $(30.4 \%)$, the most marginalized region in terms of development. As a result, it can be confirmed that the family circle is not really involved in financing projects in disadvantaged regions, due to their limited resources. It is the families themselves who need resources to survive. In fact, it is basically the inadequacy of family financial support that plays against the entrepreneurial will. This is one of the elements already set by Kozan et al., (2006) which, in their view, hinder the entrepreneurial attitude. In addition, Taylor (1996) showed that the impact of the family context on entrepreneurial engagement remains weak, mainly because of the absence or inadequacy of family affairs. This is the case for the majority of the Tunisian regions, especially the marginalized ones.

The last conclusion emphasizes the importance of the role played by the regional context in this context, thus joining the ideas of Julien and Marchesnay (1996) and Abdessalam and al., (2002). However, it is important to point out that it is in the most disadvantaged region, in terms of development (Sidi Bouzid), that the highest entrepreneurial intention is observed among students. It appears that the low level of development can be an entrepreneurial motivator. Moreover, the development of entrepreneurial intent is only the result of a set of exogenous factors relating to the context in which the individual lives. Thus, $60.8 \%$ of the interviewees of Sidi Bouzid consider that unemployment encourages them to embark on creative projects.

This seems quite normal, especially for this region, if we recall that the unemployment rate is very high, even 
reaching $48 \%$ in 2011 for young graduates, and today it accounts for 7000 university graduates. In addition, there is shortage of investment, which implies a low capacity for job creation.

The last two conclusions confirm the likelihood of having contractors who undertake by necessity and not by opportunity, thus joining the ideas of Wennekers (2006). As a result, these new entrepreneurs can be regarded as pushed into the creation of companies, which responds to negative motivations (Push effect). For these graduates, being an entrepreneur is better than being unemployed as this makes them avoid the depreciation of their human capital (Bonnet 2008). As a result, the orientation towards an independent career is mainly due to an employment problem.

Therefore, it is clear that many Tunisian entrepreneurs are motivated by the need to set up a business insofar as they do not find other opportunities for paid employment. This type of entrepreneurs often uses obsolete technologies, which do not really have a high productive efficiency. The conclusions of the World Bank's survey (2015) showed that Tunisia ranks 104th out of 140 in terms of business sophistication and 110th in terms of innovation. As a result, As a result, the Tunisian economy remains undiversified, a little innovative and weak job-creator employment for young graduates.

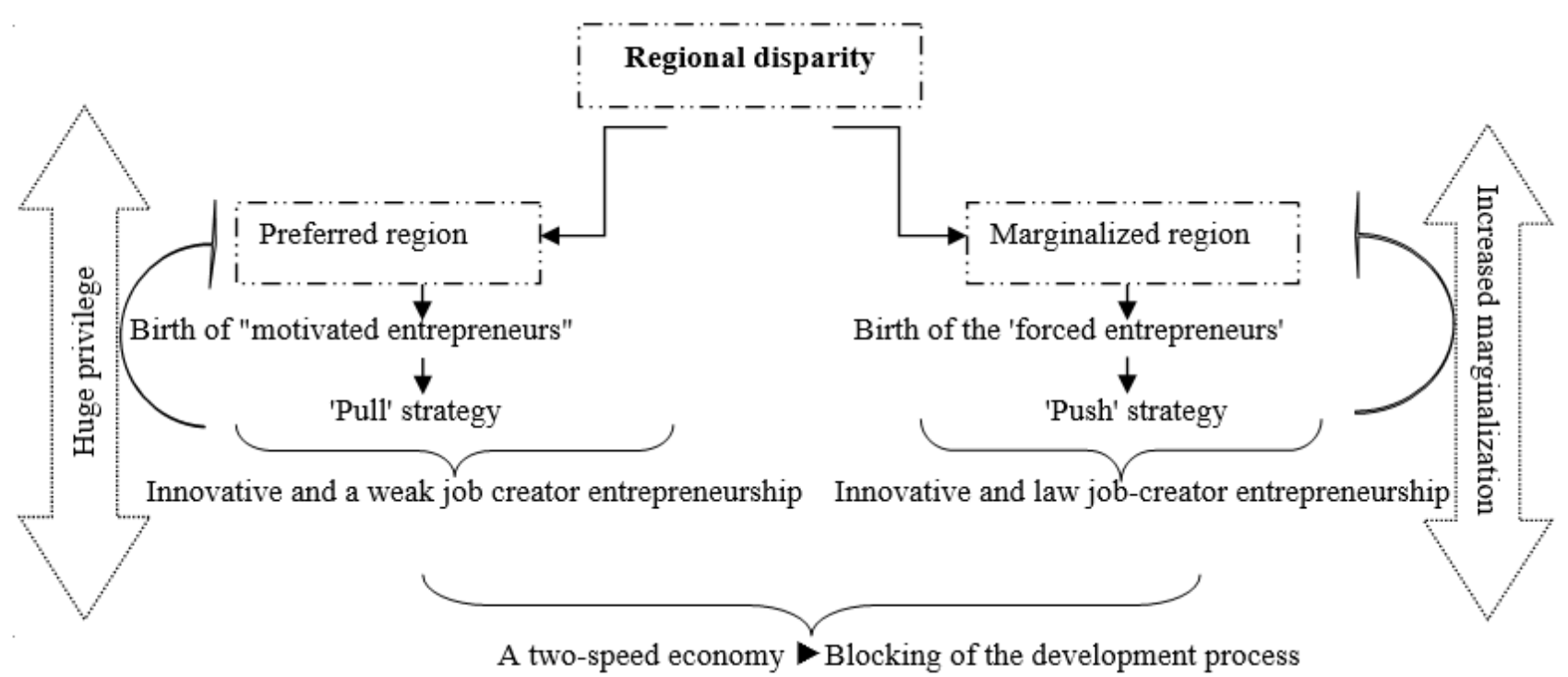

Fig. 4. Entrepreneurial dynamism in the regional disparities

As shown above (Figure 4), entrepreneurs from the privileged regions operate in a positive way, driven by the desire to create and innovate. They are then involved in a "Pull strategy" and they are called "entrepreneurs of opportunities". However, entrepreneurs who come from marginalized regions act negatively, thus operating in a "push strategy". Their main motivation is to combat unemployment and improve their social situation. In other words, business creation is not an objective in itself, but it is only a means to face a difficult context. This type of entrepreneurs is called a "constrained entrepreneur" or "entrepreneur despite himself, whose entrepreneurial intention is explained essentially by a problem of employment (Bruyat and Julien., 2001 and Couteret., 2010).

Despite contributing to the increase of investment and job creation, these entrepreneurs are still limited in their contribution to economic growth, given the nature of the launched investments (agricultural and craft industries), thus creating low value-added products. The effort in terms of innovation is still mixed, especially in relation to the most privileged regions, and the phenomenon of marginalization is getting worse. As a result, it can be confirmed that even if entrepreneurs act in an economic sphere, they strongly interact with the social sphere. Actually, contextual factors play a decisive role in the nature of the adopted entrepreneurial strategy.

\section{ENTREPRENEURIAL DEVELOPMENT REMAINS THE MIRACLE SOLUTION FOR THE SICK IN TUNISIA}

This section presents the various opportunities and challenges related to the entrepreneurial state in Tunisia. Thus, an entrepreneurial economy offers many benefits especially to the developing countries, but also poses them a lot of challenges and constraints to be quickly overcome.

\section{1. Entrepreneurship and job creation}

The Tunisian economic fabric is dominated by small and medium-sized enterprises (SMEs) engaged in traditional sectors. These companies are not able to create enough jobs for an educated and dynamic workforce. This can be 
explained by a weakness in the innovation and knowledge system, both in the public and private sectors. Moreover, in Tunisia, 38\% of GDP is realized in the context of the underground economy, according to official statistics, besides; the World Bank asserts that $54 \%$ of the workers are occupied by this economy. The magnitude of this sector can be explained by various factors, including the rigid conditions of dismis sal of workers.

The proliferation of this phenomenon cannot be without imprint on the whole economy. In fact, low wage and social costs, which affect the State's tax revenues, accelerate inflation and the rise of several other more serious problems, such as money laundering, arms and currency trade, closure of some enterprises operating in the formal sector.

Thus, the Tunisian State must help entrepreneurs motivated by the need in the informal economy to become productive workers in the formal sector in order to improve not only the level and quality of employment, but also the performance of the entire economy.

\subsection{Entrepreneurship and technological development}

It is the Tunisian State that has to encourage private companies to engage in high-tech activities. In fact, stimulating ICT investment is a necessity especially for the marginalized regions. It is in this context that one can evoke the question of the technopolis, where one counts in Tunisia a single functional technopolis (Elgazala, Tunis). All other technopolis are either in the process of being installed or in the course of studies. Five of the six technopolis under construction are located in the coastal regions, and the internal regions remain deprived of all these technological advances.

The Tunisian State is then called upon to encourage the multiplication of technopolis in all the internal regions and the integration of companies with high-tech activities into the Tunisian market, by granting tax, regulatory and financing concessions. This type of enterprise is capable of resolving in a radical way the problem of unemployment of graduates, which in a few ways favors the marginalized internal regions.

\section{3. Entrepreneurship and State's tax revenues}

In Tunisia, there are two major problems; tax pressure and injustice. Indeed, the Tunisian Central Bank says that the rate of the tax burden rose from $19.9 \%$ in 2009 to $22.5 \%$ in 2014 then dropped slightly in 2015 to $21 \%$. This rate is considered among the highest rates in the world, which can discourage entrepreneurial intent and demotivate investors.

Along the same line, the World Bank ranks Tunisia 81st out of 189 countries according to the Ease of Paying Taxes indicator. This analys is shows that the total tax rate $(59.9 \%)$ is higher than the international average (40.8\%) and the African average (46.9\%). Tunisians, in general, are more taxed than other peoples.

It is also the case that the preponderance of tax fraud, which may weaken the credibility of the State. It should be remembered that $80 \%$ of the tax revenues of the Tunisian State come from ordinary civil servants and employees, while 400000 tax payers contribute only $0.2 \%$ of the total revenue (Bouzaïene., 2015). This deprives Tunisia of a fortune that can be used to support development, particularly, in the internal regions and fight against poverty and marginalization.

A little flexibility and a lot of control are the main instruments of the State to fight against the negative effects generated by fraud and tax evasion as well as by tax havens, while always taking into account that social justice must be based on fiscal justice.

\section{4. Entrepreneurship and University; Boosting entrepreneurship for university reform}

No one can deny that the reform of the educational systems is a real entrepreneurial catalyst. In fact, entrepreneurial development can force universities to adapt to market changes. However, studies on Tunisia showed that there is a kind of shortage of human capital, which can be seen as a constraint on entrepreneurship. As already shown by Hisrich and Peters (1991) and Zouiten (2004), deficiencies in entrepreneurial education and training can hamper business creation and are among the most severe constraints faced by young entrepreneurs.

Therefore, reducing the disconnection between the taught programs and the qualifications required by companies now seems an urgency for the entrepreneurial development in Tunisia. Moreover, a study by the Arab Institute of Businessmen proves the existence of 145 thousand vacancies but what is really missing is vocational training. The Tunisian university is called upon to train people who will be able to create jobs and not people wanting to be ordinary civil servants in the State.

This state certainly had negative repercussions. Thus, according to Global Talent Competitiveness Index, Tunisia ranks 73rd out of 109 countries, thus recording weak performances in terms of talent development and skills (92nd place) and attraction of Talents (100th place). In addition, universities and higher education institutions need to increase the dynamics of partnerships with other universities, not only European but also American, Asian and African universities and with a considerable number of companies operating in various sectors.

Then, the Tunisian State is called to steer the University to be stepping stone for entrepreneurship, adopting the necessary reforms in this framework.

\subsection{Entrepreneurship and Financing}

A recent study by the ITCEQ (2016) has showed that banking financing is one of the most severe obstacles to 
the entrepreneurial process in Tunisia as it destabilizes the business climate. In fact, and according to the report of the World Bank (2016), Tunisia is ranked 126th out of 140 countries in terms of obtaining loans. $28 \%$ of Tunisian companies' financing sources come from bank loans. It was clear that self-financing predominates among Tunisian companies with a rate of $63 \%$ (ITCEQ 2010). The use of this method of financing is explained by the rigidity and inefficiency of the banking and financial system, and the importance of benefits derived from the reinvestment of profits, including tax benefits.

Along the same lines, a recent study by the Confederation of Tunisian Citizen Enterprises (2015) states that 70\% of the Tunisian SMEs have a negative working capital, which shows their inability to manage their debts.

The State must then develop new financing approaches, in particular, for the SMEs and widen the range of instruments, which essentially depends on the development of the financial market.

It is clear then that in order to build a genuine entrepreneurial economy, the authorities must put an end to a number of problems related to the general socioeconomic and political context. It is time to shed light on the future of young people who remain unemployed despite their higher education and also on the future of the internal and southern regions marginalized since the independence.

\section{CONCLUSION}

The perception of the environment and the nature of the regional space during the elaboration of the entrepreneurial strategy is our main conclusion for Tunisia. Indeed, the design of a dynamic and efficient entrepreneurial strategy must take account of the diversity of regional contexts; each regional space has its specific characteristics that strongly influence the entrepreneurial intent of individuals. It has become clear that the environment leaves its mark on the entrepreneur, imposes economic, social and cultural limits, making the context more difficult (Benredjem 2010).

We are talking mainly about unemployment among young Tunisian graduates, which favors the birth of "constrained entrepreneurs", operating within the framework of a "push strategy". This makes the entrepreneurial and thus the economic and social development of the less favored regions difficult.

To do much better, urgent measures should be launched in this domain, but it seems to us that the rise of Tunisia in the field of entrepreneurship depends mainly on a good governance and an intelligent presence of the State.

As a result, for the Tunisian case, this consists in drawing a road map centered on the development of entrepreneurial activity in the so-called "marginalized" regional areas, and focusing the effort, attention and resources on the interior of the country. In Tunisia, it is ensured year after year that boosting these regions by strengthening their entrepreneurial environments, with an emphasis on intense technology activities and encouraging start-up, helps to reduce regional disparities, combat unemployment among graduates and against poverty and develop the country as a whole.

\section{REFERENCES}

[1] Abdessalam, R., Bonnet, J. et Le Pape, N. (2002), Les modèles de créateurs/repreneurs et les facteurs de croissance des entreprises : une approche spatiale. Actes $\mathrm{du}$ XXXVIIIème colloque de l'Association de Science Régionale de Langue Française. Trois rivières, Québec.

[2] Abdesselam, R., Bonnet, J. et Le Pape, N. (2004), Les contraintes de la création et de la reprise d'entreprise: une application aux régions françaises, Cahiers d'Économie et de Sociologie Rurales, 72: 33-68.

[3] African Development Bank. (2011), Report on Development in Africa 2011, Entrepreneurship Development.

[4] Ajzen, I. (1991), The theory of planned behaviour.Organizational Behavior and Human Decision Processes, 50, 179-211.

[5] Armington, C \&Acs, Z J. (2002). The Determinants of Regional Variation in New Firm Formation.RegionalStudies 36 (1): 33-45.

[6] Audet, J. (2001), Une étude des aspirations entrepreneuriales d'étudiants universitaires québécois: Seront-ils des entrepreneurs demain? Dans Bryant, T.A. (Ed.), Actes du congrès annuel de l'ASAC, Entrepreneuriat et Affaires Familiales. London: Ontario.

[7] Audretsch, D. \& Keilbach, M. (2005), "Entrepreneurship capital and regional growth", Annals of Regional Science 39 (3).

[8] Baltagi, A. (2011), Articles Territoires et révolution tunisienne, www.academia.edu

[9] Bandura, A. (1977), "Self-efficacy: Toward a unifying theory of behavioral change", PsychologicalReview, 84(2), 191-215.

[10] Banque Africaine du Developpement. (2013), «Vers un nouveau modèle économique pour la Tunisie, contraintes majeures à une croissance généralisée », $\mathrm{BAD}$, Gouvernement de la Tunisie et Gouvernement des EtatsUnis.

[11] Benredjem, R. (2010), "L'intention entrepreneuriale : l'influence des facteurs liés à l'individu et au milieu », halshs-00528755, version 1, 22 Octobre.

[12] Binet, M.E. Facchini, F. et Koning, M. (2010), «Les déterminants de la dynamique entrepreneuriale dans les régions françaises », Revue Canadienne de Sciences Régionales, Vol. 33, pp $73-88$

[13] Block, Z. And Stumpf, S.A. (199), "Entrepreneurship Education Research: Experience and challenge, in The State of the Art of Entrepreneurship", Sexton D.L. and Kasarda J.D. Eds., Boston : PWS-Kent, 1992.

[14] Boissin, JP. Chollet, B. et Emin, S. (2008), «Les croy ances des étudiants envers la création d'entreprise: un 
état des lieux», Revue Française de Gestion, vol.34, $\mathrm{n}^{\circ} 180$.

[15] Bonnet, J. (2008), «Valorisation du capital humain, entrepreneuriat et dynamique des territoires », dans le Colloque de l'ASRDLF «Territoires et action publique territoriale, nouvelles ressources pour le développement régional », Université de Québec, Canada.

[16] Bonnet, J. (2010), «La dynamique entrepreneuriale du (des) territoire(s) français : entre firmes entrepreneuriales et entrepreneuriat lié à l'économie résidentielle », Revue Canadienne des Sciences Régionales 33, 27---38.

[17] Bouzaïene, A. (2015), «L'amnistie fiscale en Tunisie, outil de réconciliation ou prime à la fraude ?, Observatoire Tunisien de l'Economie », Note analy tique.

[18] Brusco, S. (1986), "Small firms and industrial districts: the experience of Italy", in, D. Keeble\& E. Wever (eds) New Firms and Regional Development in Europe, Croom Helm, London.

[19] Bruy at, C. and Julien, P. A. (2001), « Defining the Field of Research in Entrepreneurship", Journal of Business Venturing, vol. 16, p. 165-180.

[20] Couteret, P. (2010), «Peut-on aider les Entrepreneurs Contraints? Une étude exploratoire", Académie de l'Entrepreneuriat et de l'Innovation, Volume 9 - Numéro 2

[21] Davidsson, P. \&Wiklund, J. (1997), "Values, beliefs and regional variations in new firm formation rates", Journal of Economic Psychology, 18, 179-199.

[22] Dejardin, M. (2000), «Entrepreneuriat et croissance, une conjonction évidemment favorable? Reflets et perspectives de la vie économique », Tome XXXIX, ${ }^{\circ} 4$.

[23] Dejardin, M. (2010), "La création d'entreprises et ses rapports au territoire», Revue Canadienne des Sciences Régionales 33, 59---72

[24] Fayolle, A. \&Gailly, B. (2005), «Using the theory of planned behavior to assess entrepreneurship teaching programmers, Working paper", Center for Research in Change, Innovation and Strategy.

[25] Fora. (2008), Draft summary report BSR In---no Net WP4.March 2008.

[26] Foti, A. and Vivarelli, M. (1994), « An Econometric Test of the Self-employment Model: The Case of Italy,Small Business Economics”, 6 (2) (1994), pp. 81-93.

[27] Garofoli, G. (1993), «Economicdevelopment, organization of production and territory », Revue d'Economie Industrielle, $\mathrm{N}^{\circ} 64$.

[28] Gasse, Y. (2003), «L'influence du milieu dans la création d'entreprise », document du travail université Laval.

[29] Hayton, J. C., George, G., and Zahra, S. A. (2002), «National Culture and Entrepreneurship", A Review of Behavioral Research.

[30] Hernandez, E. M (2001), L'entrepreneuriat, approche théorique, L'Harmmattan.

[31] Hisrich, R.D. and Peters, M.P. (1991), Entrepreneurship, Economica

[32] Instauring an Advocacy Champion For Economy and Tunisia Economic Forum. (2016), Rapport annuel sur la compétitivité 2015/2016.
[33] Institut National de Statistiques. (2015), Note sur l'enquête nationale de l'emploi, http://www.ins.tn/fr/publication/note-sur-lenquêtenationale-de-l'emploi

[34] Institut Tunisien de la Competitivite et des Etudes Quantitatives. (2016), www.itceq.tn/fr (2016)

[35] Julien, P.A. \&Marchesnay, M. (1996), L'entrepreneurial, Paris, Economica, Collection Gestion/Poche.

[36] Krueger, N. F. (1993), "The impact of prior entrepreneurial exposure on perceptions of new venture feasibility and desirability", Entrepreneurship Theory and Practice, 18(1), 5-21.

[37] La Banque Mondiale et La Société Financière Internationale. (2011), «Doing Business 2012 ; Entreprendre dans un monde plus transparent », http://francais.doingbusiness.org/reports

[38] La Porta, R. and Shleifer, A. (2008), "The Unofficial Economy and Economic Development”, Brookings Papers on Economic Activity, 2, p. 275-364.

[39] Lall, S. (2004), "Reinventing industrial strategy: the role of government policy in building industrial competitiveness".UNCTAD, G-24, Discussion Paper Series.

[40] Lent, R. W., Brown, S. D., and Hackett, G. (2002), Social cognitive career theory.In D. Brown \& Associate (Eds.), Career choice and development (4th ed., pp. 255-311). San Francisco, CA: Jossey-Bass.

[41] Mckenzie, D., and Woodruff, C. (2013), "What are we learning from business training and entrepreneurship evaluations around the developing world?" World Bank Research Observer, forthcoming. Valdivia,

[42] Naudé, W. (2009), “Entrepreneurship, developing countries, and development economics: new approaches and insights", Small Business Economics, 34(1), 1-12.

[43] Nlemvo, F., Biga-Diambeidou, M. and Coeurderoy, R. (2011), «Le dynamisme entrepreneurial des régions: Proposition d'un cadre conceptuel », Canadian Journal of Regional Science, 34(2-3).

[44] OCDE. (2001), «Perspectives de la science, de la technologie et de l'industrie: Les moteurs de la croissance ; technologies de l'information, innovation et entreprenariat », OCDE, Paris.

[45] OCDE. (2004), « Promouvoir l'entreprenariat et les PME innovantes dans une économie mondialisée Vers une mondialisation plus responsable et mieux partagée, Actes de la2e conférence de l'OCDE des ministres en charge des petites et moyennes entreprises (PME)». Istanbul, Turquie.

[46] Omri, I. (2015), «La question du chômage des diplômés au Maghreb : Quelques éléments de réponse tirés de l'expérience asiatique », International Journal of Innovation and Applied Studies ISSN 2028-9324 Vol. 11 No. 3.

[47] Pluchart, J. J. (2008), «Les chaebols coréens, entre gouvernance et gouvernalité », Revue française de gestion, 2008/2 ( ${ }^{\circ} 182$ ).

[48] Programme des Nations Unies Pour Le Développement. (2011), «Durabilité et Équité : Un Meilleur Avenir pour Tous », Nations Unis. 
[49] Rajhi, N. (2014), «Conceptualisation de l'esprit entrepreneurial et identification des facteurs de son développement à l'université », Université de Grenoble.

[50] Schmitt, C. and Bayad, M. (2003), L'entrepreneuriat dans les universités françaises : regard sur le dispositif d'incubation, dans AIREPME, Actes du Colloque « L'entrepreneur en action, contextes et pratiques ", Agadir.

[51] Shapero, A. and Sokol, L. (1982), « The social dimensions of entrepreneurship". Encyclopedia of entrepreneurship, Englewood Cliffs: Prentice Hall, chap. IV, pp. 72-90.

[52] The Global Entrepreneurship and Development Institute. (2016), "Global Entrepreneurship Index 2016", https://thegedi.org/global-entrepreneurship-anddevelopment-index/

[53] The World Bank. (2016), Doing Business; Measuring Regulatory Quality and Efficiency, 13th edition.

[54] Tounes, A. (2006), "L'intention entrepreneuriale des étudiants : le cas français », Revue des Sciences de gestion, Direction et Gestion, Mai/Juin, $\mathrm{n}^{\circ} 41,219$.

[55] Verstraete, T (1999), Connaître l'entrepreneur connaître ses actes, Editions l'Harmattan collection économie et innovation.

[56] Wagner, J. (1994), "The post-entry performance of new small firms in German manufacturing industries", The Journal of Industrial Economics 2: 141-154.

[57] Wennekers, S. (2006), "Entrepreneurship at Country Level: Economic and Non-Economic Determinants", Scales Research Reports R200602, EIM Business and Policy Research.

[58] World Economic Forum. (2015), Global Competitiveness Report World Economic Forum.

[59] Zacharakis, A. L. Bygrave, W. D. and Shepherd, D. A. (2000), "Global entrepreneurship monitor: National entrepreneurship assessment: United States of America", Kaufmann Center for Entrepreneurial Leadership, Kansas City.

[60] Zouiten, J. (2004), «L'entrepreneuriat féminin en Tunisie», Actes du XVème Colloque international du CEDIMES, Alexandrie les 14-19 Mars 2004. 